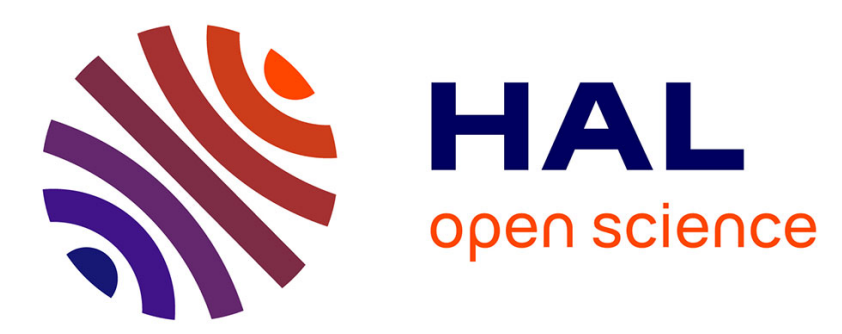

\title{
Evaluation of (Al)-Si Eutectic Reference Temperature of A3xx Alloys
}

Deni Ferdian, Jacques Lacaze

\section{To cite this version:}

Deni Ferdian, Jacques Lacaze. Evaluation of (Al)-Si Eutectic Reference Temperature of A3xx Alloys. Materials Science Forum, 2014, vol. 790-791, pp. 367-372. 10.4028/www.scientific.net/MSF.790791.367 . hal-01564670

\section{HAL Id: hal-01564670 https://hal.science/hal-01564670}

Submitted on 19 Jul 2017

HAL is a multi-disciplinary open access archive for the deposit and dissemination of scientific research documents, whether they are published or not. The documents may come from teaching and research institutions in France or abroad, or from public or private research centers.
L'archive ouverte pluridisciplinaire HAL, est destinée au dépôt et à la diffusion de documents scientifiques de niveau recherche, publiés ou non, émanant des établissements d'enseignement et de recherche français ou étrangers, des laboratoires publics ou privés. 


\section{Open Archive TOULOUSE Archive Ouverte (OATAO)}

OATAO is an open access repository that collects the work of Toulouse researchers and makes it freely available over the web where possible.

This is an author-deposited version published in : http://oatao.univ-toulouse.fr/ Eprints ID : 18078

To link to this article : DOI:10.4028/www.scientific.net/MSF.790-791.367 URL : http://dx.doi.org/10.4028/www.scientific.net/MSF.790-791.367

To cite this version : Ferdian, Deni and Lacaze, Jacques Evaluation of (Al)-Si Eutectic Reference Temperature of A3xx Alloys. (2014) Materials Science Forum, vol. 790-791. pp. 367-372. ISSN 1662-9752

Any correspondence concerning this service should be sent to the repository administrator: staff-oatao@,listes-diff.inp-toulouse.fr 


\title{
Evaluation of (Al)-Si Eutectic Reference Temperature of A3xx alloys
}

\author{
Deni Ferdian ${ }^{1,2, a}$, Jacques Lacaze ${ }^{1, b}$ \\ ${ }^{1}$ CIRIMAT, Université de Toulouse, ENSIACET, BP 44362, 31030 Toulouse, Cedex 4, France \\ ${ }^{2}$ Dept. Metallurgy and Materials, Universitas Indonesia, Kampus Baru UI Depok, 16424, Indonesia \\ adeni@metal.ui.ac.id, bjacques.lacaze@ensiacet.fr
}

Keywords: Al-Si alloys, modification, thermal analysis, eutectic reference temperature.

\begin{abstract}
The modification level of Al-Si alloys is generally evaluated by the depression of the (Al)-Si eutectic temperature which can be recorded by thermal analysis. However, this method requires a reference temperature which should be the eutectic temperature evaluated on the relevant phase diagram. Various methods proposed to account for the effect of low level alloying elements on this reference temperature are reviewed and emphasis is put on the so-called "Mondolfo's equation" which is updated. Predictions are compared to experimental information from literature.
\end{abstract}

\section{Introduction}

Thermal analysis became a widespread technique for evaluating melt preparation of aluminum alloys in the 1980's [1]. It is in particular used for checking grain refinement and eutectic modification. Several parameters have been proposed in the literature for characterizing the thermal effects seen on the cooling curves which are associated to nucleation and early growth of (Al) phase (grain refinement) and to the (Al)-Si eutectic (eutectic modification) [2-3]. Concerning eutectic modification, the most used method is to correlate the effectiveness of modification with increased eutectic undercooling or so called "eutectic depression". Evaluation of this undercooling requires the knowledge of a eutectic reference temperature which should be given by the relevant phase diagram and has often been evaluated experimentally as the eutectic temperature of the unmodified alloy. However, in many cases, this latter cannot be obtained in a cast shop due the possibility of prior modification treatment to the alloys or the use of returns in the charge.

One of the most used methods to evaluate the reference temperature of the (Al)-Si eutectic was proposed by Apelian et al. [2] who derived an equation expressing the eutectic temperature as a function of alloy's composition from the phase diagram compiled by Mondolfo [4]. The so-called "Mondolfo's equation" is still widely accepted as seen in the recent work by Wang and Lu [5]. In the present work, we first reconsider the derivation of the equation and then update it according to more recent assessed phase diagram information. We then review other approaches proposed in the literature and finally compare them to available experimental data from literature.

\section{Prediction of the solidification path of Al-Si-X alloys}

Mondolfo's equation. The equation was derived to account for the effect of six elements $(\mathrm{Cu}$, $\mathrm{Fe}, \mathrm{Mg}, \mathrm{Mn}, \mathrm{Ni}$ and $\mathrm{Zn}$ ) on the (Al)-Si eutectic with the binary (Al)-Si eutectic, $\mathrm{e}_{\mathrm{Si}}$, set at $\mathrm{w}_{\mathrm{e}, \mathrm{Si}}=12.5$ wt.\% Si and $\mathrm{T}_{\mathrm{e}, \mathrm{Si}}=577^{\circ} \mathrm{C}$. The Apelian's method considered that the effect of these elements should be additive, so that the effect of each one could be evaluated based on the related Al-Si-X ternary phase diagram. As an example, Fig. 1 shows schematically the projection of the liquidus surface of the Al-Si-Fe system (right part of the diagram) and the evolution of the (Al)-Si eutectic temperature (left part of the diagram), i.e. along the line $\mathrm{e}_{\mathrm{si}}-\mathrm{E}_{\mathrm{Fe}}$, where $\mathrm{E}_{\mathrm{Fe}}$ is the three phase invariant eutectic point between liquid, (Al), Si and $\beta-\mathrm{Al}_{5} \mathrm{FeSi}$ phase. 
Assuming linearity of the temperature change $\left(\Delta \mathrm{T}_{\mathrm{e}}\right)$ along the two-fold (Al)-Si eutectic line, we can write:

$$
\Delta \mathrm{T}_{\mathrm{e}}=\frac{\mathrm{T}_{\mathrm{e}, \mathrm{Si}}-\mathrm{T}_{\mathrm{E}, \mathrm{Fe}}}{\mathrm{w}_{\mathrm{Fe}}^{\mathrm{E}}} \cdot \mathrm{w}_{\mathrm{Fe}}^{(\mathrm{Al})-\mathrm{Si}}=\mathrm{a}_{\mathrm{Fe}} \cdot \mathrm{w}_{\mathrm{Fe}}^{(\mathrm{Al})-\mathrm{Si}}
$$

where $\mathrm{w}_{\mathrm{Fe}}^{(\mathrm{Al})-\mathrm{Si}}$ is the iron weight content along the (Al)-Si eutectic line.

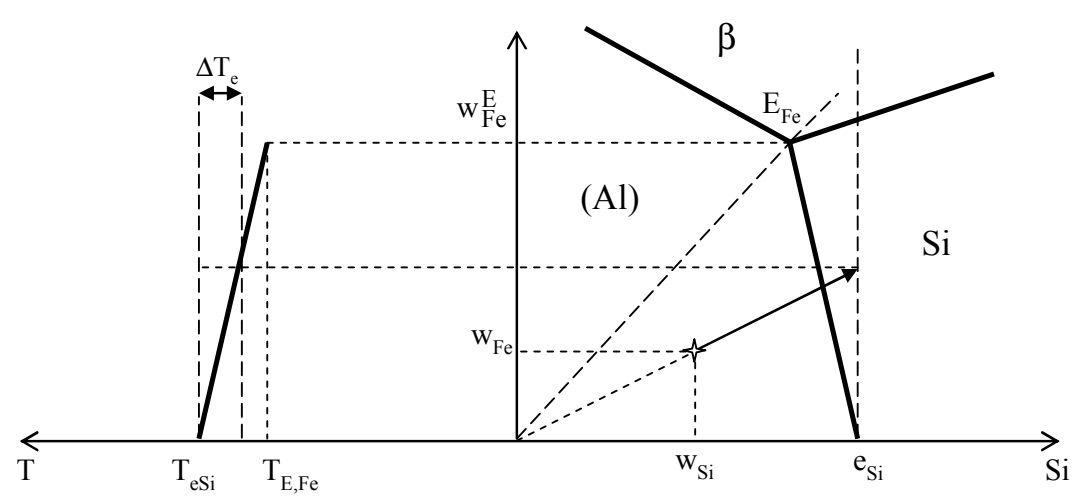

Fig. 1. Schematic Al corner of the ternary Al-Si-Fe system

For any alloy with composition $\left(\mathrm{W}_{\mathrm{Si}}, \mathrm{W}_{\mathrm{Fe}}\right)$ such as the one represented with the cross in the right side of Fig. 1, the method assumes that solidification of the (Al) primary phase leads to a liquid enrichment in $\mathrm{Fe}$ in proportion of $\frac{\mathrm{w}_{\mathrm{e}, \mathrm{Si}}}{\mathrm{w}_{\mathrm{Si}}}$ namely that $\Delta \mathrm{T}_{\mathrm{e}}=\mathrm{a}_{\mathrm{Fe}} \cdot \mathrm{w}_{\mathrm{Fe}} \cdot \frac{\mathrm{w}_{\mathrm{e}, \mathrm{Si}}}{\mathrm{w}_{\mathrm{Si}}}$. This is graphically represented with the arrow in the graph. As mentioned above, the method assumes further that the effect of alloying elements is additive, therefore the reference temperature for the start of the (Al)-Si eutectic reaction of an aluminum-silicon alloy is given as:

$$
\mathrm{T}_{\mathrm{e}}=\mathrm{T}_{\mathrm{e}, \mathrm{Si}}-\frac{\mathrm{w}_{\mathrm{e}, \mathrm{Si}}}{\mathrm{w}_{\mathrm{Si}}} \cdot \sum_{\mathrm{X}}\left(\mathrm{a}_{\mathrm{X}} \cdot \mathrm{w}_{\mathrm{X}}\right)
$$

with the sum is extended to all $\mathrm{X}$ alloying elements and the $\mathrm{a}_{\mathrm{X}}$ are defined as for Fe in equation (1).

Ternary Al-Si-X phase diagrams where $\mathrm{X}$ is $\mathrm{Fe}, \mathrm{Mg}, \mathrm{Mn}$ or $\mathrm{Ni}$, are very similar, i.e with a $\mathrm{e}_{\mathrm{si}}-\mathrm{E}_{\mathrm{X}}$ line that is at nearly constant $\mathrm{Si}$. Data relative to these diagrams and relevant to the present work are listed in Table 1, where $\mathrm{w}_{\mathrm{S}}^{\mathrm{E}, \mathrm{X}}$ and $\mathrm{w}_{\mathrm{X}}^{\mathrm{E}, \mathrm{X}}$ are the Si and $\mathrm{X}$ weight content of the ternary invariant eutectic, $\mathrm{w}_{\mathrm{X}}^{\mathrm{E},(\mathrm{Al})}$ is the $\mathrm{X}$ weight content in solid (Al) in equilibrium with the ternary eutectic liquid and $T_{E, X}$ is the three-phase eutectic temperature of the Al-Si-X system. The partition coefficients between (Al) and the liquid, $\mathrm{k}_{\mathrm{X}}$, have been evaluated with the ternary eutectic data and are also listed in the table. Mondolfo selected ternary phase diagrams mostly according to the extensive work by Phillips [6]. Recent assessment of the diagrams with $\mathrm{Fe}, \mathrm{Mg}$ and $\mathrm{Ni}$ agree with this latter while an updated version was considered for the Al-Si-Mn [7], Al-Si-Cu [8] and Al-Si-Zn [9,10] systems. For these three systems, original data according to Mondolfo's assessment are listed between brackets in Table 1.

While the method assumed the silicon content to be constant along the eutectic line, at 12.5 wt.\%, a correction is proposed here which is an attempt to account for the difference in the silicon content of the binary and ternary eutectic invariant points. Accordingly, the $\mathrm{a}_{\mathrm{X}}$ value will be calculated in the present work as:

$$
\mathrm{a}_{\mathrm{X}}=\frac{\mathrm{T}_{\mathrm{e}, \mathrm{Si}}-\mathrm{T}_{\mathrm{E}, \mathrm{X}}}{\mathrm{w}_{\mathrm{X}}^{\mathrm{E}}} \cdot \frac{\mathrm{w}_{\mathrm{Si}}^{\mathrm{E}, \mathrm{X}}}{\mathrm{w}_{\mathrm{e}, \mathrm{Si}}}
$$

Using the partition coefficients in Table 1, one can calculate the solidification path of Al-Si-X ternary alloys according to lever rule and Scheil's model. This is illustrated in Fig. 2a in the case of $\mathrm{Ni}$, where is seen that Scheil and lever rule solidification paths are nearly superimposed and lie very close to Apelian's method (arrow). These observations also apply to the other three elements, $\mathrm{Mg}$, 
Fe and Mn. However, it is also clear from the graph in Fig. 2 that the method applies only to Al-Si alloys having their composition in the triangle Al- $\mathrm{e}_{\mathrm{Si}}-\mathrm{E}_{\mathrm{X}}$. Thus, this method should be restricted to alloys with a maximum content in $\mathrm{X}$ such that the (Al)-Si eutectic precipitates before any other secondary eutectic phase. This maximum, $w_{X}^{\max }$, depends on the alloy's Si content and is roughly given as:

$$
\mathrm{w}_{\mathrm{X}}^{\max }=\frac{\mathrm{w}_{\mathrm{Si}}}{\mathrm{w}_{\mathrm{Si}}^{\mathrm{E}, \mathrm{X}}} \cdot \mathrm{w}_{\mathrm{X}}^{\mathrm{E}, \mathrm{X}}
$$

Table 1. Ternary eutectic points data of selected Al-Si-X ternary systems. See the text for definitions; compositions are in wt.\% and temperature in Celsius. Values assessed by Mondolfo are between brackets when they have been updated.

\begin{tabular}{|c|c|c|c|c|c|c|c|c|}
\hline Element & $\mathrm{w}_{\mathrm{Si}}^{\mathrm{E}, \mathrm{X}}$ & $\mathrm{w}_{\mathrm{X}}^{\mathrm{E}, \mathrm{S}}$ & $\mathrm{w}_{\mathrm{X}}^{\mathrm{E},(\mathrm{Al})}$ & $\mathrm{k}_{\mathrm{X}}$ & $\mathrm{T}_{\mathrm{E}, \mathrm{X}}$ & Original factor $\mathrm{a}_{\mathrm{X}}$ & $\frac{\mathrm{w}_{\mathrm{Si}}^{\mathrm{E}, \mathrm{X}}}{\mathrm{w}_{\mathrm{e}, \mathrm{Si}}}$ & $\begin{array}{c}\text { Present } \\
\text { work } \\
\text { factor } \mathrm{a}_{\mathrm{X}}\end{array}$ \\
\hline $\mathrm{Mg}$ & 12.95 & 0.85 & 4.96 & 0.171 & 555 & 4.43 & 1.036 & 4.59 \\
\hline $\mathrm{Fe}$ & 12 & 0.05 & 0.7 & 0.071 & 576 & 1.43 & 0.96 & 1.37 \\
\hline $\mathrm{Cu}^{*}$ & $6(5)$ & 4.5 & $25.6(27)$ & 0.175 & $521(525)$ & 1.93 & 0.75 & 1.65 \\
\hline $\mathrm{Zn}$ & $4.2(3)$ & & $40(80)$ & & $535(440)$ & 1.7 & 0.336 & 0.35 \\
\hline $\mathrm{Mn}$ & $12.7(12)$ & 0.03 & $0.4(1)$ & 0.075 & $576(574)$ & 3 & 1.016 & 2.54 \\
\hline $\mathrm{Ni}$ & 11 & 0.05 & 5 & 0.01 & 557 & 4 & 0.88 & 3.52 \\
\hline
\end{tabular}

For alloys with low level in alloying elements such as A356 where the total content in elements other than $\mathrm{Al}$ and $\mathrm{Si}$ is less than $1 \mathrm{wt} . \%$, the accuracy of Apelian's method is quite good in predicting the (Al)-Si eutectic reference temperature. However, the equation fails to predict it correctly for aluminum-silicon alloys with high $\mathrm{Cu}$ alloying content such as A319 [3]. The reason for this is evidenced when considering the Al-Si-Cu phase diagram in Fig. $2 b$ drawn according to He et al. [8]. It is seen that the (Al)-Si eutectic line moves far away to the left of the line at $12.5 \mathrm{wt}$. $\% \mathrm{Si}$ along with increasing copper content. This leads to copper contents as estimated by the method much higher than the one when the solidification path reaches the (Al)-Si eutectic line. The maximum overestimation of the copper content is obtained for the ternary eutectic point when the method would give 2.5 (i.e. 12.5/5.0) times too high copper content. This means that the $\mathrm{a}_{\mathrm{Cu}}$ coefficient as listed in Table 1 as "original factor" should be multiplied by 0.4 . Because the actual copper contents in the Al-Si alloys are much lower than the value at the ternary eutectic point, the correction can not be that dramatic in all practicality. With the experimental data analyzed below, it has been found that a multiplication factor of 0.75 gives appropriate results, i.e. $\mathrm{a}_{\mathrm{Cu}}$ was set to 1.65 after accounting for the effect of Si ternary eutectic content, see Table 1. The Al-Si-Zn phase diagram is somehow similar to the $\mathrm{Al}-\mathrm{Si}-\mathrm{Cu}$ one in that the ternary invariant eutectic is located far away from the binary (Al)-Si eutectic, and in fact is very close to the Zn-rich corner of the phase diagram. For this system and owing to the low $\mathrm{Zn}$ levels in A3xx alloys, it seemed wiser to use the reported isopleth section at 5.3 at.\% $\% \mathrm{Si}[9,10]$ to estimate the effect of $\mathrm{Zn}$ on the two-fold (Al)-Si saturation line. The corresponding data is shown in Table 1 where it is seen that the final estimate of $a_{\mathrm{Zn}}$ differs greatly from the one assessed with the Apelian's method.

To sum up, the following equation is proposed that incorporates the changes of silicon content along the eutectic lines as well as an updating of the ternary phase diagrams:

$$
\mathrm{T}_{\mathrm{e}}\left({ }^{\mathrm{o}} \mathrm{C}\right)=577-\frac{12.5}{\mathrm{w}_{\mathrm{Si}}} \cdot\left(4.59 \cdot \mathrm{w}_{\mathrm{Mg}}+1.37 \cdot \mathrm{w}_{\mathrm{Fe}}+1.65 \cdot \mathrm{w}_{\mathrm{Cu}}+0.35 \cdot \mathrm{w}_{\mathrm{Zn}}+2.54 \cdot \mathrm{w}_{\mathrm{Mn}}+3.52 \cdot \mathrm{w}_{\mathrm{Ni}}\right)
$$

This equation itself shows it is restricted to silicon content higher than 1 wt.\%. Therefore, the equation should be limited to silicon contents in the range 1 to $12.5 \mathrm{wt} . \%$ and to alloying additions that depend on the silicon content, see Eq. 4, and are at most (wt.\%) 4.9 for $\mathrm{Mg}, 0.7$ for Fe, 5 for $\mathrm{Cu}, 5$ for $\mathrm{Zn}, 0.4$ for $\mathrm{Mn}$ and 5 for $\mathrm{Ni}$. 

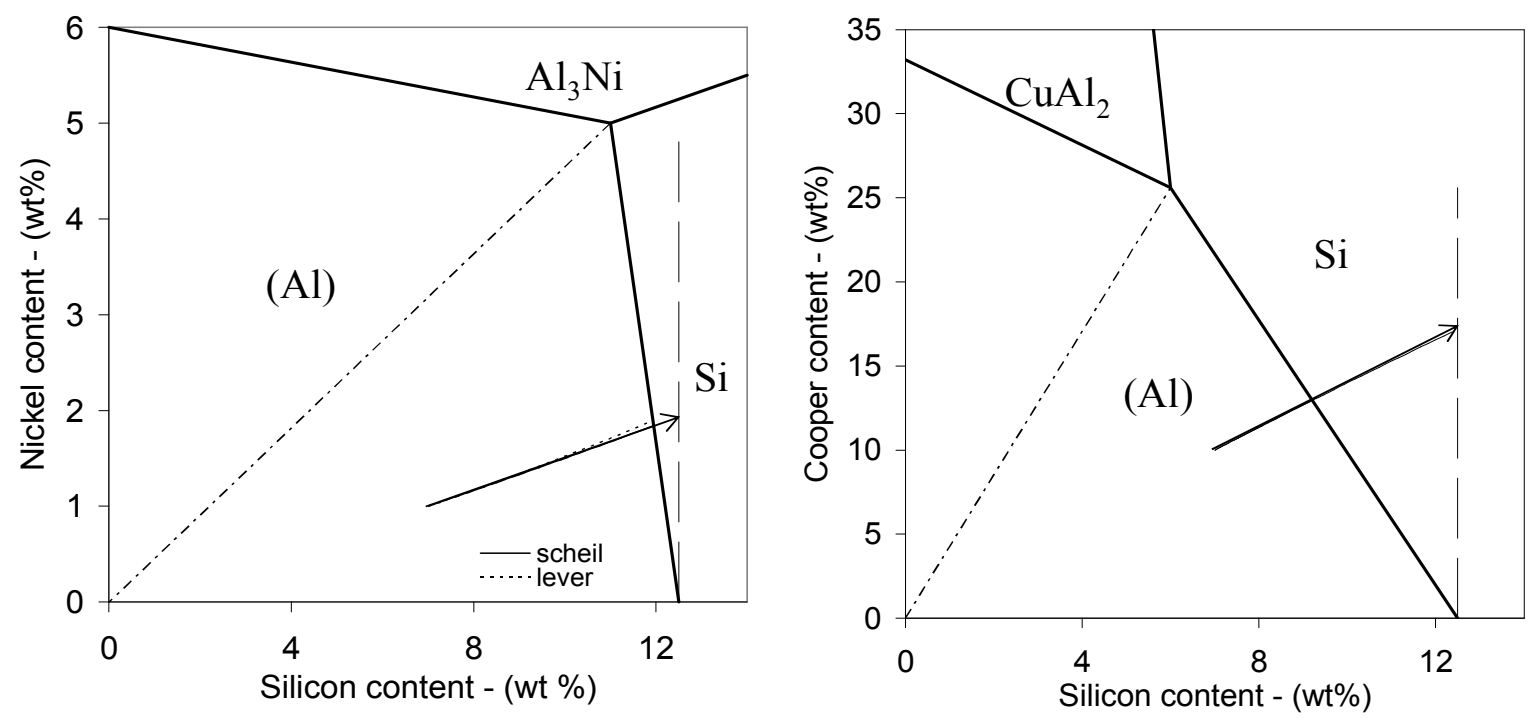

Fig. 2. Solidification path plotted onto the liquidus projection of the ternary Al-Si-Ni (a) and Al$\mathrm{Si}-\mathrm{Cu}$ (b) phase diagrams. Arrows illustrates Apelian's method, while Scheil's and lever rule paths are hindered below them.

Other equations. There are several other approaches proposed to calculate the reference eutectic temperature. Studies by Joenoes and Gruzleski [11] which focused on the magnesium effect, proposed a series of empiric calculations with a coefficient depending on the Si content in the alloys. While those equations only consider one element in the calculation and are limited to one type of chemical composition, Sthuldreier et al. [12] considered 3 major elements, $\mathrm{Mg}, \mathrm{Cu}$ and $\mathrm{Fe}$ based on their experimental data. A different approach was used by Djurdjevic and collaborators $[13,14]$ who described the (Al) liquidus with second order polynomial for binary Al-X systems of interest and then defined a silicon equivalent $\left(\mathrm{Si}_{\mathrm{eq}}\right)$ for each element $\mathrm{X}$. Then, the enrichment of the liquid is described as with the Apelian's method and the eutectic temperature writes as follows:

$$
\mathrm{T}_{\mathrm{e}}=660.452-\left(6.11 \cdot \mathrm{Si}_{\mathrm{eq}}+0.057 \cdot \mathrm{Si}_{\mathrm{eq}}^{2}\right) \cdot\left(\frac{12.3}{\mathrm{w}_{\mathrm{Si}}}\right)
$$

\section{Result and Discussion}

A comparison of reference temperatures predicted with equations from the present work, Apelian et al. [2], Stuhldreier et al. [12] and Djurdjevic [14], with thermal analysis data from literature [2,14-25] is shown in Figure 3a. In addition, comparison with calculations made with Thermo-Calc and the TCAL1 database [26] according to Scheil's model are also shown in Fig. 3b. In the literature data, two different methods are used to extract the eutectic temperature from the cooling curves which relate to recording the plateau temperature, $\mathrm{T}_{\mathrm{E}, \mathrm{G}}$, and the nucleation temperature, $\mathrm{T}_{\mathrm{E}, \mathrm{Nuc}}$ respectively. The method using the nucleation temperature gives systematically much higher temperatures than that predicted by CALPHAD calculations. Though such an observation may need further investigation, it suggests that the change in the cooling rate as recorded with thermal analysis cups and associated to nucleation in the central part of the cup, may relate in fact to the heat released by the outer part of the cup where the eutectic transformation has started. In a way, the reading of thermocouple would be influenced by the heat flux released from the outer shell of the thermal analysis cup.

The graph shows that at high eutectic temperature with low alloying additions, equations by Apelian et al. [2] and Stuhldreier et al. [12] present a low deviation from the bisector line. However, their predictions become scattered as the eutectic temperature is lowered due to higher alloying element. Moreover, the silicon equivalent method proposed by Djurdjevic [14] predicts values significantly above the experimental results in all the composition ranges investigated. 

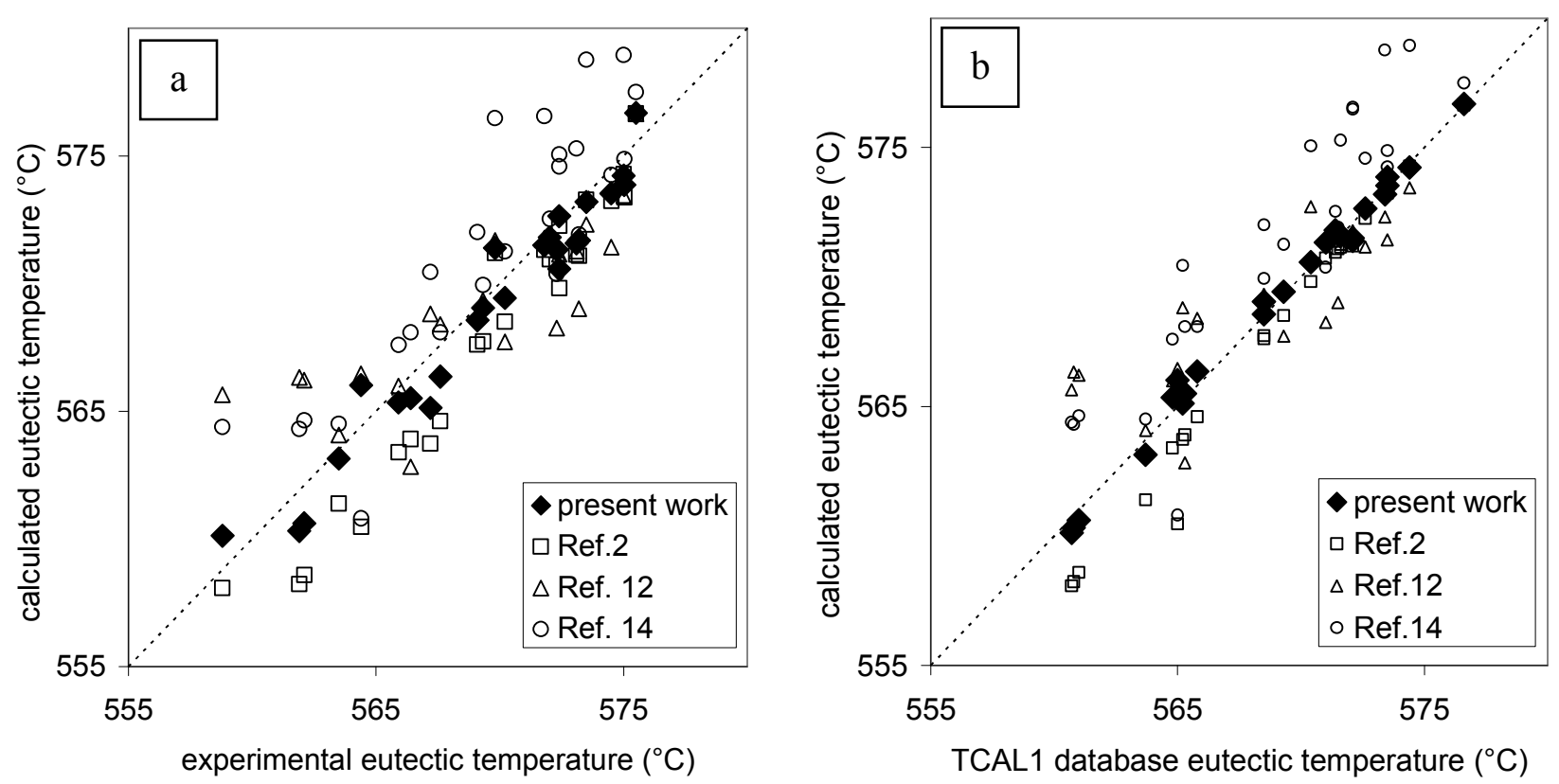

Fig. 3. Graph showing the correlation between experimental data (a), TCAL1 database (b) and calculated eutectic temperatures according to present work, Apelian et al. [2], Stuhldreier et al. [12] and Djurdjevic [14]. The dotted line are bisectors.

\section{Conclusion}

The so-called Mondolfo's equation derived by Apelian et al. [2] does agree quite well with the experimental and CALPHAD results for low $\mathrm{Cu}$ alloys, while giving too low values otherwise. The present approach that accounts empirically of the effect of $\mathrm{Cu}$ does closely follow CALPHAD-type predictions. It is finally seen that the proposed equation shows a better agreement with the experimental data than other equations in the whole range of compositions.

\section{Acknowledgments}

The authors wish to acknowledge the financial support received from the European Space Agency (contract \#4200014347) through the MICAST program and DGHE - Indonesia Education Ministry.

\section{References}

[1] B.L. Tuttle, Principle of thermal analysis for molten metal process control, Proc. AFS/CMI Conf., Rosemont, IL, USA (1984) 1-37.

[2] D. Apelian, G.K. Sigworth, K.R. Whaler, Assessment of grain refinement and modification of Al-Si foundry alloys by thermal analysis, AFS Trans. 92 (1984) 297-307.

[3] J.E. Gruzleski, B.M. Closset, The treatment of liquid aluminum-silicon alloys, AFS Inc., Des Plaines, Illinois, 1990.

[4] L.F. Mondolfo, Aluminum alloys: structure and properties, Butterworth, London, 1976.

[5] R.Y. Wang, W. Lu, Spheroidization of eutectic silicon in direct-electrolytic Al-Si Alloy, Metall. Mater. Trans. A, 44 (2013) 2799-2809.

[6] H.W.L. Phillips, Annotated equilibrium diagrams of some aluminium alloy systems, Monograph No. 25, Inst. Met., London, 1959.

[7] Y. Du, Z. Jin, B. Huang, W. Gong, H. Xu, Z. Yuan, J.C. Schuster, F. Weitzer and N. Krendelsberger, A thermodynamic description of the Al-Mn-Si system over the entire composition and temperature ranges, Metall. Mater. Trans. A. 35 (2004) 1613-1628. 
[8] C.Y. He, Y. Du, H.L. Chen, and H. Xu, Experimental investigation and thermodynamic modeling of the Al-Cu-Si system, CALPHAD 33 (2009) 200-210.

[9] K. Suzuki, M. Kagayama, Y. Takeuchi, Eutectic phase equilibrium of Al-Si-Zn system and its applicability for lower temperature brazing, J. Jpn. Inst. Light Met. 43 (1993) 533-538. (in Japanese)

[10] M.H.G. Jacob and P.J. Spencer, A critical thermodynamic evaluation of the systems Si-Zn and Al-Si-Zn, CALPHAD 20 (1996) 307-320.

[11] A.T. Joenoes and J.E. Gruzleski, Magnesium effects on the microstructure of unmodified and modified Al-Si alloys, Cast met. 4 (1991) 62-72.

[12] G. Stuhldreier, E. Mettingen, K.W. Stoffregen, Erfahrungen mit thermischen analyse von GAlSi-legierungen, Giesserei.68 (1981) 404-409.

[13] F.C. Robles Hernandez, M.B. Djurdjevic, W.T. Kierkus, J.H. Sokolowski, Calculation of the liquidus temperature for hypo and hypereutectic aluminum silicon alloys, Mater. Sci. Eng., A. 396 (2005) 271-276.

[14] M.B. Djurdjevic, Thermal description of hypoeutectic Al-Si-Cu alloys using silicon equivalency, Military Technical Courier. 60 (2012) 152-168.

[15] J. Charbonnier, Microprocessor assisted thermal analysis testing of aluminum alloy structure, AFS Trans.92 (1984) 907-921.

[16] S. Gowri, F.H. Samuel, Effect of alloying elements on the solidification characteristics and microstructure of Al-Si-Cu-Mg-Fe 380 alloy, Metall. Mater. Trans. A, 25A (1994) 437-448.

[17]. M.B. Djurdjevic, H. Jiang, J. Sokolowski, Online prediction of aluminum-silicon eutectic modification level using thermal analysis, Mater. Charact., 46 (2001) 31-38.

[18] S. Thompson, S.L. Cockroft, M.A. Wells, Advance light metals casting development: solidification of aluminum alloy A356, Mater. Sci. Technol. 20 (2004) 194-200.

[19] M.B. Djurdjevic, G. Huber, Z. Odanovic, Synergy between thermal analysis and simulation, J. Therm. Anal. Calorim.111 (2013) 1365-1373.

[20] S. Farahany, A. Ourdjini, M.H. Idrsi, S.G. Shabestari, Evaluation of the effect of Bi, Sb, Sr and cooling condition on eutectic phases in Al-Si-Cu alloy (ADC12) by in situ thermal analysis, Thermochim. Acta, 2013, vol.553, pp. 59-68

[21] Y.M. Han, A.M. Samuel, F.H. Samuel, H.W. Doty, Microstructure characteristics in nonmodified and $\mathrm{Sr}$ modified $\mathrm{Al}-\mathrm{Si}-\mathrm{Cu}-\mathrm{Mg} 319$ type alloys, Int. J. Cast Met. Res, 2008, vol.21, pp. 371-380.

[22] S. Thompson, S.L. Cockroft, M.A. Wells, Advanced light metals casting development: solidification of aluminium alloy A356, Mater. Sci. Technol., 2004, vol.20, pp.194-200.

[23] S.D. McDonald, A.K. Dahle, J.A. Taylor, D.H. StJohn, Eutectic grains in unmodified and strontium-modified hypoeutectic aluminum-silicon alloys, Metall. Mater. Trans. A, 2004, Vol.35A, pp. 1829-1873.

[24] M.B. Djurdjevic, G. Huber, Z. Odanovic, Synergy between thermal analysis and simulation, J. Therm. Anal. Calorim., 2013, vol.111, pp. 1365-1373

[25] M.B. Djurdjevic, Z. Odanovic, N. Talijan, Characterization of the solidification path of AlSi5Cu(1-4 wt.\%) alloys using cooling curve analysis, JOM, 2011, vol.63, pp. 1-7.

[26] Thermo-Calc Software, TCAL1 database version 1.0, http://www.thermocalc.com (Accessed 29 March 2013). 


\section{Solidification and Gravity VI}

10.4028/www.scientific.net/MSF.790-791

\section{Evaluation of (AI)-Si Eutectic Reference Temperature of A3xx Alloys}

10.4028/www.scientific.net/MSF.790-791.367

\section{DOI References}

[8] C.Y. He, Y. Du, H.L. Chen, and H. Xu, Experimental investigation and thermodynamic modeling of the Al-Cu-Si system, CALPHAD 33 (2009) 200-210.

http://dx.doi.org/10.1016/j.calphad.2008.07.015

[9] K. Suzuki, M. Kagayama, Y. Takeuchi, Eutectic phase equilibrium of Al-Si-Zn system and its applicability for lower temperature brazing, J. Jpn. Inst. Light Met. 43 (1993) 533-538. (in Japanese). http://dx.doi.org/10.2464/jilm.43.533

[10] M.H.G. Jacob and P.J. Spencer, A critical thermodynamic evaluation of the systems Si-Zn and Al-Si-Zn, CALPHAD 20 (1996) 307-320.

http://dx.doi.org/10.1016/S0364-5916(96)00033-8

[18] S. Thompson, S.L. Cockroft, M.A. Wells, Advance light metals casting development: solidification of aluminum alloy A356, Mater. Sci. Technol. 20 (2004) 194-200.

http://dx.doi.org/10.1179/026708304225011199

[19] M.B. Djurdjevic, G. Huber, Z. Odanovic, Synergy between thermal analysis and simulation, J. Therm. Anal. Calorim. 111 (2013) 1365-1373.

http://dx.doi.org/10.1007/s10973-012-2389-0 